\title{
Chlorophyll content and degrees day accumulation in passion fruit species in the Southwest of Goias, Brazil
}

Karminne Dias do Valle', Vanessa Brenda Souza Chaves', Laísse Danielle Pereira', Edésio Fialho dos Reis', Alejandro Hurtado Salazar²*, Danielle Fabíola Pereira da Silva'

'Federal University of Goias, Jataí, Brazi

${ }^{2}$ University of Caldas, Manizales, Colombia

*Corresponding author, e-mail: alhuza@gmail.com

\begin{abstract}
Brazil is considered the world's largest passion fruit producer, which benefits the entire crop chain of production and generates demand for production. The aim of this study was to evaluate the growth, thermal requirements and leaf morphological aspects of passion fruit species. The experiment was conducted at the Federal University of Goias (UFG)- Jataí, evaluating the following characteristics: leaf area, chlorophyll content (TCC) and thermal accumulation, being expressed in days after planting. To determine the total chlorophyll content, assessments were made in the middle third of the leaf blade, evaluating the accumulation of thermal units until flowering, from the average temperatures of the region. The daily temperature data were obtained from the meteorological station of the UFG - Jataí (17053'08" S and 51 $40^{\circ} 12^{\prime \prime}$ O). The cultivar FB 200 and Maracujazeiro-azedo presented higher leaf area, having the last one higher chlorophyll content in leaves and FB 200 presented lower demand in thermal units accumulation, proving its precocity.
\end{abstract}

Keywords: Passiflora edulis f. flavicarpa, Passiflora alata, development

\section{Introduction}

During the last 30 years the passion fruit production has been expanding as a whole and attracting growers throughout Brazil (Meletti et al., 2011). The production of passion fruit in Brazil in 2016 was 703,489 thousand of tons, with 49,889 hectares of planted area, in which the state of Goias, Brazil, produced 6,099 tons, corresponding to only $0.87 \%$ of the national production (Agrianual, 2017). Although the crop is planted in the State, mainly in the Southwest, there are no productions on a commercial scale (IBGE, 2017). In the passion fruit crop, leaf area determination provides a foundation for physiological studies, involving plant growth, light interception, photosynthefic efficiency, evapotranspiration and response to fertilizers and irrigation (Morgado et al., 2013). For this reason, understanding the growth and development of passion fruit allows the implementation of management strategies for high yield.

Chlorophyll is a green pigment that absorbs light and is directly related to the photosynthetic efficiency of plants, allowing its growth and adaptability to different environments (Taiz \& Zeiger, 2017). Most of the methods used to determine chlorophyll content are destructive and time consuming, involving the use of a spectrophotometer. Alternative solutions were developed to estimate pigment concentration 
using optical methods that are non-destructive, resulting in cheaper and fast analysis, which can be applied in field conditions (Morgado et al., 2013).

Therefore, it is necessary to determine the parameters related to plant development to define plant conduction strategies. In this context, the analysis of the factors such as plant growth, development and thermal requirements favors the knowledge of the phenological phases, contributing to the understanding of the whole plant cycle (Matos et al., 2014).

Cycle and crop development are important aspects, considering that they define the plant phenological changes and, therefore, the phases of growth. A simple and widely used model to define the crop stage of development is the method known as degrees day (Ometto, 1981).

According to Salazar et al. (2016), the degrees day concept of a plant species takes into consideration the termal sum required for each phenological phase of the crop cycle. The results of this thermal sum are different among plant varieties. Thus, plant growth models have shown that in very high temperature scenarios, crop cycles decrease, reducing yield (Streck and Alberto, 2006, and Costa et al., 2009).

The leaf area can be used as plant responses to growth by means of photoassimilates and the chlorophyll content, which has close relation the photosynthetic rate (Salazar et al., 2016).

The adoption of low cost, non destructive and efficient methodologies for measuring leaf area and chlorophyll content is essential for the expansion of the research with Passiflora species. The aim of this study was to evaluate the leaf area, chlorophyll content and degrees day accumulation during the growth and development of Passiflora plants, with nondestructive methods, using linear measurements of leaves of different Passiflora species in the Southwest of Goias, Brazil.

\section{Materials and Methods}

The experiment was conducted at the Federal University of Goiás - Jataí, Brazil. The orchard of the experiment is located in the following geographical coordinates: latitude $17^{\circ}$ $53^{\prime}$ South and longitude $51^{\circ} 43^{\prime}$ West, with $670 \mathrm{~m}$ of altitude. The climate of the region, according to Köppen's classification is Aw, megatermic, with the dry season defined from May to September, and the rainy season, from October to April (Cardoso et al., 2014).

The treatments consisted of testing the cultivars FB 200 (Flora Brazil), Maracujazeiroazedo (Passiflora edulis f. Flavicarpa) and Maracujazeiro-doce (Passiflora alata). The experiment was set in a completely randomized design, with three treatments (genotypes), five periods of evaluation $(30,45,58,65$ and 72 days after planting), with four repetitions, being composed of five plants each. The evaluations were carried out over time after planting the seedlings in the field $(30,45,58,65$ and 72 days after planting - DAP).

After reaching the size between 0.80 and $1.50 \mathrm{~m}$, the seeds were transplanted (September, 2016) to the field according to recommendations of Damatto-Júnior et al. (2014); in a 3×4 m spacing, in a trellis system with drip irrigation. The samplings were carried out during the period of growth, development and beginning of flowering of the species under study, which occurred between September and November, 2016.

For the leaf area analysis (LA), it was considered that the leaf morphology can be different according to the species, from oblongovate to trilobate. The methodology followed by non-destructive measurement of the leaf area was proposed by Morgado et al. (2013), where the length of the main vein (L) and the width between the ends (W) were measured in the species with complete leaves (nonlobed). These measurements were made using a $0.1 \mathrm{~cm}$ precision ruler. The ' $\mathrm{L} \times \mathrm{A}$ ' product was the independent variable in the equation $y=0.596944 x-0.000821 x^{2}+1,49412692 \cdot 10^{-6} x^{3}$ $\left(R^{2}=0,99 * *\right)$ (Casierra-Posada et al., 2007).

To determine the total chlorophyll content, evaluations were carried out in the middle third of the leaf lamina. Three readings were performed with the chlorophyllometer ClorofiLOG, model CFL 1030, operated according to the manufacturer's specifications (Falker, 2008). This procedure was performed in each 
plant and evaluated in five mature leaves of the middle part. The chlorophyll meter provides values named Falker Chlorophyll Index (ICF) proportional to the absorbance of chlorophylls.

To evaluate the accumulation of thermal units up to flowering, daily temperature data were obtained from the Agrometeorological station of UFG-Regional Jataí (17053'08 "S and $\left.51^{\circ} 40^{\prime} 12^{\prime \prime} O\right)$. For the characterization of the thermal requirements, the sum of degrees days (DD) from the seedling phase to the flowering was calculated, using equations 1,2 and 3 , according to Ometto, (1981).

in which: DD: daily value of the degrees day; TM: maximum temperature; Tm: minimum temperature, TB: maximum basal temperature; and Tb: minimum basal temperature; considering the minimum basal temperature of $10^{\circ} \mathrm{C}$ and the maximum, $36^{\circ} \mathrm{C}$ (Neves et al. 1999).

$$
D D=\left(\frac{T M-T m}{2}\right)+(T m-T b)
$$

when: $\mathrm{Tm}>\mathrm{Tb}$ and $\mathrm{TM}<\mathrm{TB}$

$$
D D=\frac{(T M-T b)^{2}}{2(T M-T m)}
$$

when: $\mathrm{T} m<\mathrm{Tb}$ and $\mathrm{TM}<\mathrm{TB}$

$D D=\frac{2(T M-T m)(T m-T b)+(T M-T m)^{2}-(T M-T B)^{2}}{2(T M-T m)}$

when: $\mathrm{Tm}>\mathrm{Tb}$ and $\mathrm{TM}>\mathrm{TB}$

The data were submitted to variance analysis and comparison of means by the Duncan test, using the SAS software (StatisticaL Analysis System, 2013).

\section{Results and Discussion}

At 30 DAP, it was observed a larger leaf area for FB 200 and 'Maracujazeiro azedo', differing statistically from the 'Maracujazeiro doce' (sweet passion fruit) (Table 1).

The determination of the leaf area is of great importance for the determination of the amount of water transpired by the plants. Leaf area monitoring explains the physiological characteristics that are related to plant growth, photosynthetic relationships and transpiration processes (Morgado et al., 2013), since the leaves are the main organs responsible for photosynthesis.

The observations made at 45, 58, 65 and 72 DAP for the leaf area did not differ statistically between treatments FB 200 and 'Maracujazeiroazedo'. However, it was observed a divergent behavior for the 'Maracujazeiro doce' genotype, which differed from the other treatments, demonstrating a reduced photosynthetic activity in the genotype and larger area. The coefficients of variation for leaf area in the first evaluations (30 and 45 DAT) were superior to $30 \%$, indicating a high dispersion of the data, possibly due to the lower maturity of the leaves of the middle third of the plant.

Sousa et al. (2013), evaluating growth, mineral composition and total phenotypes of Passiflora genotypes as a function of nitrogen sources, concluded that the Passiflora edulis genotype presented a higher leaf area among the compared genotypes. The results observed by the authors regarding the leaf development are in agreement with the behavior observed for the genotypes 'Maracujazeiro-azedo' and FB 200 at 72 days after transplanting in the present study.

Table 1. Leaf area $\left(\mathrm{cm}^{2}\right)$ and chlorophyll content (TCC) of passion fruit genotypes FB 200, 'Maracujazeiro doce' and 'Maracujazeiro azedo'. Jataí-GO, Brazil 2016.

\begin{tabular}{llllll}
\hline \multirow{2}{*}{ Genotype } & \multicolumn{5}{c}{ Leaf area $\left(\mathrm{cm}^{2}\right)$} \\
\cline { 2 - 6 } & \multicolumn{5}{c}{ Days after planting } \\
\cline { 2 - 6 } & 30 & 45 & 58 & 65 & 72 \\
\hline FB 200 & $69.78 \mathrm{a}$ & $84.84 \mathrm{a}$ & $86.32 \mathrm{a}$ & $82.97 \mathrm{ab}$ & $92.44 \mathrm{a}$ \\
Maracujazeiro-doce & $43.16 \mathrm{~b}$ & $59.48 \mathrm{~b}$ & $63.60 \mathrm{~b}$ & $75.21 \mathrm{~b}$ & $73.54 \mathrm{~b}$ \\
Maracujazeiro-azedo & $64.15 \mathrm{a}$ & $70.29 \mathrm{ab}$ & $85.46 \mathrm{a}$ & $90.44 \mathrm{a}$ & $90.91 \mathrm{a}$ \\
\hline CV (\%) & 40.45 & 31.29 & 22.95 & 19.43 & 19.8 \\
\hline & \multicolumn{5}{c}{ Total chlorophyll content (TCC) } \\
\cline { 2 - 6 } & $45.97 \mathrm{~b}$ & $49.65 \mathrm{a}$ & $49.24 \mathrm{~b}$ & $47.91 \mathrm{~b}$ & $49.96 \mathrm{a}$ \\
\hline FB 200 & $54.05 \mathrm{a}$ & $49.37 \mathrm{a}$ & $44.78 \mathrm{~b}$ & $38.54 \mathrm{C}$ & $41.04 \mathrm{~b}$ \\
Maracujazeiro-doce & $56.22 \mathrm{a}$ & $55.07 \mathrm{a}$ & $55.90 \mathrm{a}$ & $55.47 \mathrm{a}$ & $54.17 \mathrm{a}$ \\
Maracujazeiro-azedo & 16.63 & 15.76 & 16.44 & 17.73 \\
\hline CV (\%) & \multicolumn{5}{c}{18.9}
\end{tabular}


According to Taiz \& Zeiger (2017), leaves with largest area do not have the better results of growth and crop survival under stressful conditions, due to the exposition of a large surface area for water evaporation, which can lead to rapid soil water deficit or excessive and harmful absorption of solar energy. Plants can reduce their leaf area by decreasing leaf cell division and expansion, altering leaf forms and initiating senescence and leaf abscission. This phenomenon can lead to certain types of heterofilia. This is how sweet passion fruit plants (Maracujazeiro-doce) can also present an efficient use of water along with the ability to adapt to high light conditions, as presented in the development of this study.

At 30 days after planting a chlorophyll content of 56.22 and 54.05 was observed for 'Maracujazeiro-azedo' and 'Maracujazeirodoce', respectively, with no significant difference (Table 1). According to Vendruscolo et al. (2017), the chlorophyll content is directly related to the nutritional status of the plant and the yield, which in turn has a strong correlation with the nitrogen concentration.

No diferences were observed between treatments at 45 days after planting and the chlorophyll contents were 55.07 for
'Maracujazeiro azedo', 49.65 to 'Maracujazeiro doce' and 49.37 to FB 200. At 58 days after planting the chlorophyll content of the genotype 'Maracujazeiro azedo' were statistically different from the other treatments, with an average of 55.90, while the 'Maracujazeiro doce' and the cultivar FB 200 did not differ.

At 65 DAT, it was verified that the genotype 'Maracujazeiro azedo' presented a higher average than the other treatments, being statistically different from these. At 72 DAP, it was possible to observe that plants of the cultivar FB 200 and 'Maracujazeiro azedo' presented similar behavior, but with no statistical difference.

At 72 days after planting, it was observed for plants of the cultivar FB200 a chlorophyll content of 92.44, and 73.54 for 'Maracujazeirodoce' and 90.91 for 'Maracujazeiro-azedo', wich were not statistically diferent.

The period of observation of the behavior of the plant to the accumulation of thermal units (degrees day) until the flowering corresponded to a growing photoperiod, with average daily temperatures oscillating beyond the range considered ideal for the plant, which is between 23.65 and $28.00^{\circ} \mathrm{C}$ (Table 2).

Table 2. Degrees day for the beginning of flowering of the plants of the genotypes FB 200, 'Maracujazeiro doce' and 'Maracujazeiro azedo' from seeds at 270 DAP, Jataí, Go, Brazil.

\begin{tabular}{ccc}
\hline Genotypes & Degrees-day & Number of evaluated days \\
\hline FB200 & 1717.05 & 116 \\
Maracujazeiro-doce & 1832.65 & 123 \\
Maracujazeiro-azedo & 1942.11 & 130 \\
\hline
\end{tabular}

Lower requirements in thermal units was observed for plants of the cultivar FB200, confirming its precocity. The increasing order of degree days demand for flowering began with the commercial cultivar FB 200, followed by the 'Maracujazeiro doce' and 'Maracujazeiro azedo'.

The result in relation to the vegetative development for FB200 was, from the initial juvenile stage to the flowering, the sum of accumulated degrees day of 1717.05 DD, being diferent from the observed by Souza et al. (Passiflora edulis Sims), during 190 days of evaluation, which observed that was necessary 2500 DD from the initial phase until the maturation of the fruits
(2010), when studying the relation between accumulation of degrees day, photothermal units and vegetative growth of Passiflora edulis Sims.

The requirements to complete the cycle for plants of the cultivar FB 200 were 1717.05 degrees day in 116 days after planting (DAP). Similar values were observed by Salazar et al. (2016) for the genotype Passiflora edulis, which obtained a total of 1717.62 degrees day in an evaluation period of 189 days, confirming that the cultivar FB 200 completed its phenological stage or cycle in a shorter time when compared to other cultivars or genotypes.

The precocity in the FB200 cultivar 
cycle, depending on the degrees days required to complete the cycle, makes it promising as an option for cultivation. In addition, a lower requirement was observed in thermal units and higher leaf area indexes. This is desirable because it is directly related to some physiological phenomena, such as: photosynthesis, respiration, water consumption and transpiration, as has been observed in studies involving fruit physiology and vegetables yield.

Plants of 'Maracujazeiro azedo' and of the FB 200 cultivar presented the highest values of leaf areas. The chlorophyll content was higher for the genotype 'Marcujazeiro azedo'. Plants of the cultivar FB 200 were less demanding in DD accumulation, completing their cycle in 116 days, which lead to higher precocity among the studied genotypes.

\section{References}

Agrianual. Anuário de agricultura brasileira. São Paulo: FNP Consultoria e Comércio, 2017. 523 p.

Cardoso, M. R. D., Marcuzzo, F. F. N., Barros, J. R. 2014. Classificação Climática de Köppen-Geiger para o Estado de Goiás e o Distrito Federal. ACTA Geográfica, 8: 40-55.

Casierra, F.P., Cardozo, M., Cárdenas. J.H.F. Análisis del crecimiento en frutos de tomate (Lycopersicon esculentum Mill.) cultivados bajo invernadero 2007. Agronomía Colombiana, 25: 299-305.

Costa, L. C., Justino, F., Oliveira, I. J. C., Sediyama, G. C., Ferreira, W. P. M., Lemos, C. F. 2009. Potential forcing of $\mathrm{CO}_{2}$, technology and climate changes in maize (Zea mays) and bean (Phaseolus vulgaris) yield in southeast Brazil. Environmental Research Letters, 4: 1-10.

Damatto-Junior, E. R., Fuzitani, E. J., Nomura, E. S. 2014. Produção de maracujá com uso de mudas avançadas no Vale do Ribeira. Pesquisa \& Tecnologia, 11: 66-71.

Falker, Automação agrícola. Manual do medidor eletrônico de teor clorofila (ClorofiLOG/CFL 1030). Porto Alegre, 2008. 33p. Disponível em: $<$ http://www.falker.com.br/produto_download. php?id=4>. Acesso em: 06 ago. 2017.

IBGE. 2017. Banco de dados agregados do Instituto Brasileiro de Geografia e Estatística. Produção Maracujá 2015. Disponível em: http:// www.sidra.ibge.gov.br. Acesso em: 18 de Agosto de 2017.

Matos, V. A. T., Pivetta, F., Sobrinho, S.P., Tissiani,
A. S.O., Pereira, A. P. M. S., Ramos, F. T., \& Júnior, J. H. C. 2014. Temperaturas basais e exigência térmica para a maturação de caju. Bioscience Journal, 30: 122-131.

Meletti, L. M. M. 2011. Avanços na cultura do maracujá no Brasil. Revista Brasileira de Fruticultura, 33: 83-91.

Morgado, M. A. D., Bruckner, C. H., Rosado, L. D. S., Assunção, W., dos Santos, C.E.M. 2013. Estimação da área foliar por método não destrutivo, utilizando medidas lineares das folhas de espécies de Passiflora. Revista Ceres, 60: 662667.

Neves, C., Carvalho, S., Neves, P. 1999. Porcentagem de frutificação, período de desenvolvimento dos frutos e unidades térmicas para maracujá amarelo. Revista Brasileira de Fruticultura, 21: 128-130.

Ometto, J. C. Bioclimatologia vegetal. São Paulo: Agronômica Ceres 1981. 440p

Salazar, A. H., Silva, D. F. P. da, Picoli, E. T., Bruckner, C. H. 2016. Desenvolvimento, florescimento e análise morfoanatômica do maracujazeiroamarelo enxertado em espécies silvestres do gênero passiflora. Revista Brasileira de Ciências Agrárias, 11: 90-96.

Sousa, L.B., Heitor, L. C., Santos, P. C. dos, Altoé, J. A. F., Freitas, M. S. M. de, Freitas, S. D. J., Carvalho, A. J. C. de. 2013. Crescimento, composição mineral e fenóis totais de espécies de Passiflora em função de fontes nitrogenadas. Bragantia, 72: 122-131.

Souza, F.E., Chig, L.A., Costa, R.H., Batista, J., Campelo, J.H. 2010. Relação entre acumulo de graus-dia e de unidades fototermicas e crescimento vegetativo do maracujazeiro roxo (Passiflora edulis Sims). Uniciências, 14: 39-51.

Statistical Analysis System. SAS Institute Cary, N.C. EEUU. Version 9.6. 2013.

Streck, N. A., Alberto, C. M. 2006. Estudo numérico do impacto da mudança climática sobre o rendimento de trigo, soja e milho. Pesquisa Agropecuária Brasileira, 41: 1351-1359.

Taiz, L. Zeiger, E. Fisiologia vegetal. 6. ed. Porto Alegre: Artmed, 2017. 858 p.

Vendruscolo, E. P., Martins, A. P. B., Seleguini, A. 2017. Doses e parcelamento de niacina no desenvolvimento inicial de meloeiro Cantaloupe. Revista agro@mbiente on-line, 11: 209-214. 